Y. LIU, Q. CHEN, C. MOU, L. PAN*, X. DUAN, X. CHEN, H. CHEN, Y. ZHAO, Y. LU, Z. JIN, Y. R. CHI* (NANYANG TECHNOLOGICAL UNIVERSITY, SINGAPORE; GUIYANG UNIVERSITY OF CHINESE MEDICINE AND GUIZHOU UNIVERSITY, GUIYANG, P. R. OF CHINA)

Catalytic Asymmetric Acetalization of Carboxylic Acids for Access to Chiral Phthalidyl Ester Prodrugs Nat. Commun. 2019, 10, 1675.

\title{
Phthalidyl Ester Prodrugs by Catalytic Asymmetric Acetalization of Carboxylic Acids
}

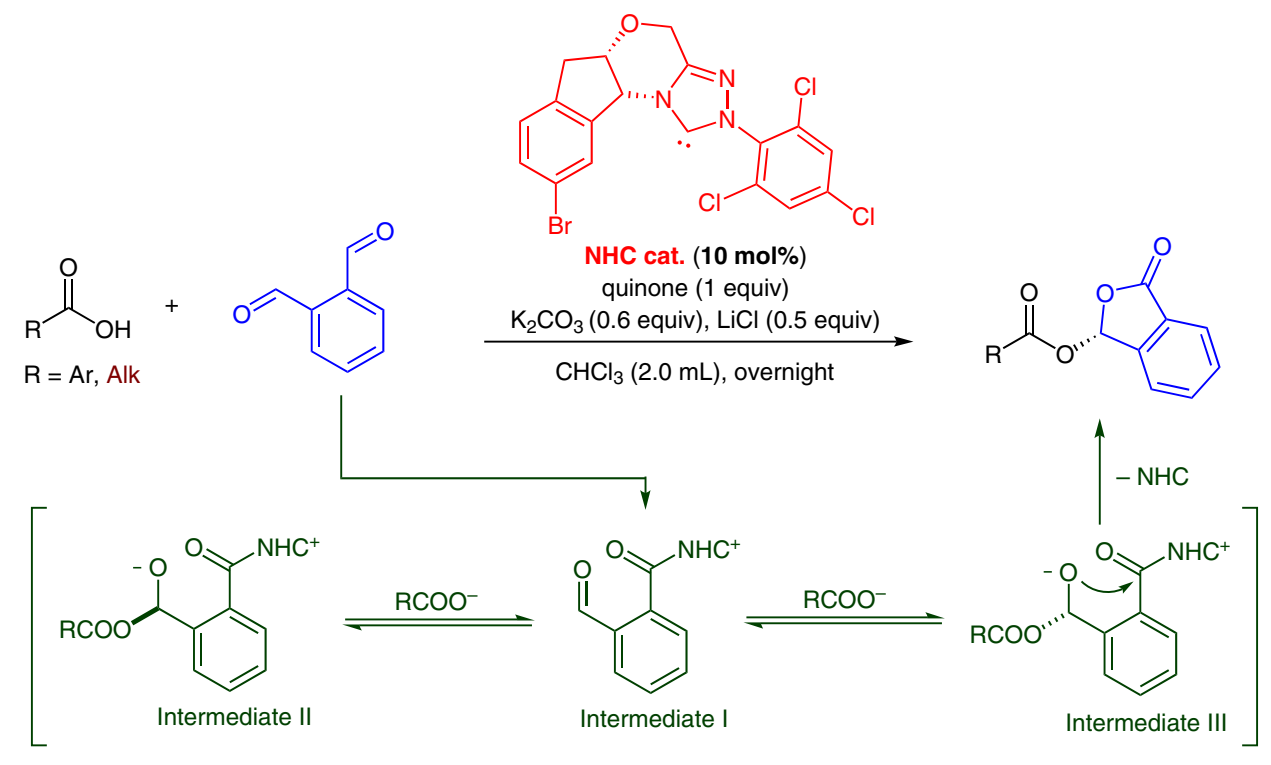

Selected examples:<smiles>Cc1ccccc1C(=O)O</smiles>

$94 \%$ yield er $=92: 8$

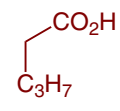

$68 \%$ yield er $=98: 2$<smiles>O=C(O)c1ccccc1-c1ccccc1</smiles>

$82 \%$ yield er $=92: 8$

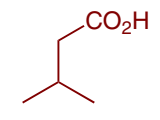

$55 \%$ yield er $=97: 3$<smiles>O=C(O)c1cccc2ccccc12</smiles>

$58 \%$ yield er $=91: 9$<smiles>O=C(O)CCCC(=O)c1ccccc1</smiles>

$96 \%$ yield er $=94: 6$<smiles>Cc1ccc(C(=O)O)cc1</smiles>

\section{$72 \%$ yield} er $=94: 6$

$90 \%$ yield er $=92: 8$

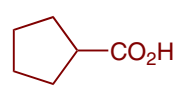

$91 \%$ yield<smiles>O=C(O)c1ccc2c(c1)OCO2</smiles>

$79 \%$ yield er $=94: 6$

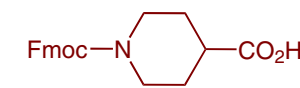

$86 \%$ yield er $=98: 2$
Significance: The authors report an NHC-catalyzed asymmetric acetalization of carboxylic acids that provides efficient access to chiral phthalidyl ester prodrugs. Phthalidyl esters are conventionally prepared by treating carboxylic acids with 3-bromophthalides, but this standard approach exhibits poor stereoselective control over the newly created chiral center.

\section{Category}

Organo- and Biocatalysis

\section{Key words}

phthalidyl ester prodrug

asymmetric catalysis

acetalization

NHC catalysis
Comment: Interestingly, higher average enantioselectivities were obtained with aliphatic acid substrates than with aromatic acid substrates. However, stronger acids such as trifluoroacetic acid proved to be poor substrates for this transformation due to the lower nucleophilicities of their corresponding anions and the poor stabilities of the subsequent reaction intermediates. 